\title{
The Mind of the Nation: The Debate about Völkerpsychologie, 1851-1900
}

Egbert Klautke

School of Slavonic and East European Studies, University College London

Will be published in Central Europe 8.1 (2010)

\begin{abstract}
Völkerpsychologie or 'folk psychology' has a bad reputation amongst historians. It is either viewed as a pseudo-science not worth studying in detail, or considered a 'failure' since, in contrast to sociology, psychology, and anthropology, it never established itself as an independent discipline at university level. This article argues that Völkerpsychologie as developed by Moritz Lazarus and Heymann Steinthal was an important current in nineteenth-century German thought. While it was riddled with conceptual and methodological problems and received harsh criticism from academic reviewers, it contributed to the establishing of the social sciences since key concepts of folk psychology were appropriated by scholars such as Georg Simmel and Franz Boas. The article summarizes the main features of Lazarus and Steinthal's Völkerpsychologie, discusses it reception in Germany and abroad, and shows how arguments originally developed for folk psychology were used by Lazarus to reject antisemitism in the 1870 s and 1880 s. It concludes that Lazarus and Steinthal's Völkerpsychologie epitomized the mentality of nineteenth-century liberals with its belief in science, progress, and the nation, which was reinforced by their experience of Jewish emancipation.
\end{abstract}

\section{Key terms}


Völkerpsychologie; antisemitism; Germany; philosophy; psychology; social sciences;

Lazarus, Moritz; Steinthal, Heymann

\section{Introduction}

Völkerpsychologie or 'folk psychology' has a bad reputation amongst historians. ${ }^{1}$ It is either viewed as a pseudo-science not worth studying in detail, or considered a 'failure' since, in contrast to sociology, psychology and anthropology, it never established itself as an independent discipline at university level. In the period between the 1860 s and the 1890s, however, Völkerpsychologie as outlined and championed by Moritz Lazarus and Heymann Steinthal, played an important role in the post-Hegelian reconfiguration of the humanities. As such, while being criticized and even ridiculed by some contemporary commentators, the reception of key concepts of folk psychology contributed to the establishing of the social sciences in Germany and abroad. The main problem of folk psychology as conceived by Lazarus and Steinthal, then, derived from the political uses of their approach, not from theoretical or methodological inconsistencies. Their idea of Völkerpsychologie was closely related to their position as emancipated Jews who identified strongly with the Prussian-German state. As such, Völkerpsychologie purported to analyse the psychology of nations, including that of Jews; the 'spirit' of the Jews they claimed to be not merely national, but rather universally human in a way that transcended nationality.

1

The term Völkerpsychologie is notoriously difficult to translate into English. It has been rendered as ‘folk psychology', 'national psychology', ‘anthropological psychology', or 'ethnic psychology', none of which give an accurate translation of the German original but rather testify to the changing understanding of the term over time. I use 'folk psychology' as the historical translation of Völkerpsychologie, even though this term is used in contemporary cognitive psychology and philosophy of the mind in a different meaning, i.e. to describe lay-psychological reasoning. After the founding of the German Empire, Lazarus used the terms Volk and Nation as synonyms, but preferred the former. 
Furthermore, Lazarus and Steinthal denied that the Jews constituted a 'nation'; in their view, they were a confession within the German nation. Taken to its logical conclusion, this argument would have destroyed the notion of a unified, harmonious Volksgeist on which the whole idea of a 'folk psychology' depended, since it would have called for a definition of the nation as an diverse mixture of different religious, regional, and other 'spirits'. In this article, I shall provide a summary of the concept of Völkerpsychologie as developed by Lazarus and Steinthal, analyse the main lines of the reception of their approach, and show how they employed key arguments of Völkerpsychologie to counter antisemitic accusations in the $1870 \mathrm{~s}$ and $1880 \mathrm{~s}^{2}$

\section{Lazarus and Steinthal's concept of Völkerpsychologie}

In 1851, Moritz Lazarus (1824-1903) introduced the term Völkerpsychologie or 'folk psychology' into scholarly debates in a short article, published in the journal Deutsches Museum, which outlined the main aims and arguments of a new academic discipline. ${ }^{3}$ In 1859, together with Heymann Steinthal (1823-99), he expanded this text into a manifesto for the newly-established Zeitschrift für Völkerpsychologie und Sprachwissenschaft, subsequently published in twenty volumes until $1890 .{ }^{4}$ Both Lazarus and Steinthal were

2 The material used in this article is part of a larger study on the history of Völkerpsychologie which will be published by Berghahn Books, New York and Oxford.

3 Moritz Lazarus, 'Über den Begriff und die Möglichkeit einer Völkerpsychologie', Deutsches Museum. Zeitschrift für Literatur, Kunst und öffentliches Leben, 1, 1851, pp. 112-126.

$4 \quad$ Moritz Lazarus and Heyman Steinthal, 'Einleitende Gedanken über Völkerpsychologie, als Einladung zu einer Zeitschrift für Völkerpsychologie und Sprachwissenschaft', Zeitschrift für Völkerpsychologie und Sprachwissenschaft, 1, 1860, pp. 1-73. See Georg Eckardt (ed.), Völkerpsychologie - Versuch einer Neuentdeckung: Texte von Lazarus, Steinthal und Wundt, Weinheim, 1997; Christian Köhnke, 'Einleitung', in Moritz Lazarus, Grundzüge der Völkerpsychologie und Kulturwissenschaft ed. Christian Köhnke, Hamburg, 
typical products of the emancipation of the Jews in Prussia in the nineteenth century. They both grew up in provincial Prussia: Lazarus in the small town Filehne (Wieleń) in the province of Posen (Poznań), a typical Central European 'microcosm' with an ethnically and confessionally mixed population; Steinthal in the town of Gröbzig in Anhalt. ${ }^{5}$ Both came from respected, lower-middle class Jewish families with strong ties to the local Jewish communities, and both used the new opportunities in higher education to leave the Jewish milieu of their parents' generation behind. While attending the Gymnasium, Lazarus experienced a short, but severe, crisis of identity when he broke with the orthodox Jewish faith of his family and turned himself into a secular, national-liberal Jewish German. According to Gershom Scholem, Lazarus was thus the epitome of the nineteenth-century assimilated German Jew, who completed the transition from purely Talmudic Judaism to a new German-Jewish identity in only five years. ${ }^{6}$

At the University of Berlin, where they had met as students of the linguist Carl Heyse, both Lazarus and Steinthal abandoned plans to study theology and become rabbis, and they immersed themselves instead in studying philosophy and the humanities. ${ }^{7}$ Steinthal completed his Habilitation, the 'second doctorate' that had become a precondition for teaching at a German university because of the decline in the standards of doctoral dissertations, in 1847 and became a Privatdozent, an unsalaried lecturer and member of the faculty. An eminent and productive linguist, Steinthal published a series of monographs on

2003, pp. ix-xlii.

$5 \quad$ Ingrid Belke, 'Einleitung', in Moritz Lazarus und Heymann Steinthal: Die Begründer der Völkerpsychologie in ihren Briefen, ed. by Ingrid Belke, 3 vols., Tübingen, 1971-86, vol. 1, pp. xiv-xv; 1xxxii. 6 Gershom Scholem, 'Juden und Deutsche', in G. Scholem, Judaica, vol. 2, Frankfurt am Main, 1970, pp. 20-46, at p. 32; Belke, 'Einleitung', vol. 1, p. xxvii.

$7 \quad$ Belke, 'Einleitung', vol. 1, p. xxiii. 
historical and systematic linguistics. ${ }^{8}$ After an extended research trip to Paris in 1852-56, made possible by the award of the Prix Volney, Steinthal returned to Berlin in 1856 and became adjunct professor at the university in $1862 .{ }^{9}$ Lazarus, in turn, after graduating with a doctorate in philosophy, worked as an independent scholar and established a literary and scholarly salon at his flat in Berlin, financially supported by his wife's family. In 1859 he became professor at the University of Bern on the basis of two volumes entitled The Life of the Soul, an eclectic collection of his philosophical and psychological writings. ${ }^{10}$ Despite the success and recognition his academic work received in Switzerland, Lazarus gave up his secure position at the University of Bern and returned to the Prussian capital when his wife inherited a large sum of money in $1866 .{ }^{11}$ He hoped to be appointed to a chair in philosophy at a German university, but several attempts to install him at the University of Kiel failed. ${ }^{12}$ From 1868 to 1872 he taught philosophy at the Prussian Military Academy in Berlin, and in 1873 he was given an honorary chair (ordentlicher Honorarprofessor) in

Belke, 'Einleitung', vol. 1, pp. lxxxv-lxxxvii. Heymann Steinthal, Die Classification der Sprachen, dargestellt als die Entwickelung der Sprachidee, Berlin, 1850. Idem, Der Ursprung der Sprache, im Zusammenhange mit den letzten Fragen alles Wissens. Eine Darstellung der Ansicht Wilhelm von Humboldts, verglichen mit denen Herders und Hamanns, Berlin, 1851. Idem, Die Wurzeln der verschiedenen chinesischen Dialekte, Berlin, 1854. Idem, Grammatik, Logik und Psychologie, ihre Prinzipien und ihr Verhältnis zueinander, Berlin, 1855. Idem, Geschichte der Sprachwissenschaft bei den Griechen und Römern mit besonderer Rücksicht auf die Logik, 2 vols., Berlin, 1863. Idem, Die Mande-Neger-Sprachen. Psychologisch und phonetisch betrachtet, Berlin, 1867.

$9 \quad$ Belke, 'Einleitung', vol. 1, pp. xcv-xcviii; see Lazarus to Heymann Steinthal, 21 December 1855, in Belke, Lazarus, vol. 1, p. 93; Steinthal to Lazarus, 11 December 1855, in Belke, Lazarus, vol. 1, p. 286.

10 M. Lazarus, Das Leben der Seele in Monographien über seine Erscheinungen und Gesetze, 2 vols., Berlin, 1856-57.

11 Belke, 'Einleitung', vol. 1, pp. xxvi-xxvii; Nahida Lazarus, Ein deutscher Professor in der Schweiz. Mit Briefen und Dokumenten im Nachlaß ihre Gatten, Berlin, n. d.) [1910 or 1911]. 
philosophy at the University of Berlin. Lazarus's continued success as a public speaker and teacher - his first lecture on Völkerpsychologie at the University of Berlin in 1873-74 attracted more than 120 students and had to be moved to a larger lecture theatre - and the sales of his books made him one of the most celebrated and well-known popular philosophers of the late nineteenth century. ${ }^{13}$ But despite public recognition of his work (both the University of Bern and the Hebrew Union College in Cincinnati, Ohio, awarded him honorary doctorates, and on his seventieth birthday, the emperor of Germany and Prussian king Wilhelm II made him a Geheimer Regierungsrat), Lazarus did not reach the highest step of the academic ladder, a full professorship at a German university. Despite this snub that he shared with Steinthal, their biographies represent success stories of Jewish emancipation and assimilation in Prussia and Germany. ${ }^{14}$

Lazarus and Steinthal presented folk psychology as an attempt to synthesize the rapidly increasing store of philosophical and historical knowledge, and coherently to interpret the material that individual disciplines had amassed. The causa causans of history was the 'folk spirit' (Volksgeist), in all its appearances, that formed the object of study of Völkerpsychologie. The aim of the new discipline was to discover the 'laws' that governed the historical development of nations and thus to establish a 'social science'. Such a discipline was overdue, Lazarus and Steinthal argued. Since man was a social being and could only exist as part of a national community, and since a nation represented more than

Belke, 'Einleitung', vol. 1, p. xl; Lazarus to Eduard Rese, 20 May 1873, in Belke, Lazarus, vol. 1, p. 124; Lazarus to Eduard Rese, 7 December 1873, in Belke, Lazarus, vol. 1, p. 128. 
the sum of its parts, folk psychology was the necessary extension of individual psychology. They adopted the romantic term Volksgeist or 'folk spirit', but tried to strip it of its idealistic connotations: the folk spirit was a not a metaphysical idea, Lazarus and Steinthal claimed, but simply described the 'essence of all inner and higher activity' of a nation, as expressed in the language, myths, religion, customs and habits of the nation that Völkerpsychologie would study systematically. ${ }^{15}$

Lazarus and Steinthal were followers of Joseph Friedrich Herbart (1776-1841), the German philosopher who had succeeded Kant in the chair in philosophy at the University of Königsberg. Lazarus had been introduced to Herbart's works as a mature student at the Gymnasium, remained a follower of his psychology for all his life, and thus became a main representative of 'Herbartianism' in Germany. Herbart, they claimed, had been close to ‘finding Völkerpsychologie’, but had stopped short of extending his psychological system to the study of groups and nations. ${ }^{16}$ The second important inspiration for folk psychology was Wilhelm von Humboldt: Steinthal was a life-long, critical follower of his linguistic works. Both Lazarus and Steinthal agreed with Humboldt that linguistic differences represented, by and large, essential differences between nations: 'The logical forms of thinking are intricately linked to language, and everyone who understands the essence of language correctly will find out that completely different forms of speaking simply reflect

\footnotetext{
15 Lazarus and Steinthal, 'Einleitende Gedanken', pp. 27-28.

16 Ibid., p. 7, Belke, 'Einleitung', vol. 1, pp. 1-li. See Andreas Hoeschen and Lothar Schneider (eds), Herbarts Kultursystem. Perspektiven der Transdisziplinarität im 19. Jahrhundert, Würzburg, 2001; Andreas Hoeschen, Lothar Schneider, 'Herbartianismus im 19. Jahrhundert: Umriß einer intellektuellen Konfiguration', in Lutz Raphael (ed.), Ideen als gesellschaftliche Gestaltungskraft im Europa der Neuzeit: Beiträge für eine erneuerte Geistesgeschichte, Munich, 2006, pp. 447-77.
} 
completely different forms of speaking. ${ }^{17}$ Hence, language was the most important object of 'folk psychology'; Steinthal understood most of his linguistical studies as contributions to folk psychology.

Even though, by following Herbart, Lazarus and Steinthal consciously dissociated themselves from the Hegelianism that dominated the University of Berlin in the 1840s, they could not escape Hegelian influences. In fact, already as a student, Lazarus had hoped to reconcile the philosophical systems of Herbart and Hegel. The most obvious borrowing from Hegel's philosophy was the concept of an 'objective spirit'. Lazarus and Steinthal used the term to describe the intellectual heritage of the Volk. The objective spirit thus contained the accumulated knowledge of generations, from the most basic technical knowledge to the most elaborate constructions of art and science, and was thus of vital importance for the constitution of any community. The folk spirit turned the multitude of individuals into a coherent people since it functioned as the "bond, the principle, and the idea of a people' through which a nation acquired its unity and became a harmonic, organic entity. ${ }^{18}$ The most basic terms of their approach, 'nation' or 'folk' (Volk) and 'folk spirit' (Volksgeist) were defined in a circular way; it remained unclear which came first: nation or folk spirit. Lazarus and Steinthal had reached the 'limits of the sayable' since they were only capable of apprehending man as belonging to a nation, and history as national history.

Nevertheless, Lazarus and Steinthal proposed an idea that went beyond the conventional wisdom of middle-class intellectuals who yearned for a unified German

17

Lazarus and Steinthal, 'Einleitende Bemerkungen', p. 30: 'Mit der Sprache hängen dann die logischen Formen des Denken aufs Innigste zusammen, und Jeder, dem das Wesen der Sprache im wahren Lichte erscheint, wird erkennen, daß grundverschiedene Redeformen nur die Erscheinung grundverschiedener Denkformen sind.' 
nation-state. Their definition of the Volk introduced a notion that came close to modern theories of nations and nationalism on account of its rejection of all 'objective' definitions. Language was considered an important common trait of nations as the representation of the 'folk spirit'. However, defining the nation by language alone was considered insufficient; different nations used the same language, and multilingual nations such as Switzerland existed. Nor could common descent - Lazarus and Steinthal avoided the term 'race' define a nation since all nations were ethnically mixed. Instead, Lazarus and Steinthal presented the nation as the product of the will of its members to form a nation, and thus the result of an active decision. A nation depended on the subjective view of its members of their equality and unity. Despite its subjective origins, nations were no less 'real'; they could still be 'found' as facts throughout history. The nation was a mental product of the individuals who belonged to it and was thus endlessly re-created. The nation was the 'first product of the folk spirit' 19

Nations, then, did not possess a fixed and immutable character, but underwent constant changes. Normally, nations progressed and reached higher levels of perfection, but they could also decline. Repeating a central idea of historicist thinking, Lazarus and Steinthal saw the development of nations as parallel to the development of individuals who through education and experience formed a specific character that constituted a closed 'totality'. The 'rise' of a nation's level of learning and education happened 'for particular reasons and according to specific laws'. It was these laws that folk psychology would study systematically. ${ }^{20}$ One of the main aims of the new discipline was to study the relationship between the individual and the community. Lazarus described this relationship as an 
interaction (Wechselwirkung), since the individual was inconceivable without belonging to a group, and groups in turn were formed by individuals. But, ultimately, the nation prevailed over the individual. As Lazarus and Steinthal explained, 'Each and every mental deed of an individual' was rooted in the 'folk spirit' and could only be explained by analysing the peculiarities of the folk spirit. ${ }^{21}$

Völkerpsychologie was intended to reorganize the system of disciplines that studied the development of nations and of man as a social being. All of these disciplines were flawed, according to Lazarus and Steinthal. Anthropology was, therefore, one-sided, because it explained the differences between nations solely as a consequence of their physical environment and the climate. 'Ethnology' reduced man to a 'product of nature' and treated him as an animal, neglecting his essentially spiritual and intellectual qualities. Philosophy, on the other hand - that is, Hegel and his followers - neglected empirical facts, and indulged in theoretical-deductive speculations that were not founded in reality. History and geography, in turn, were too descriptive, anecdotal, and lacked the systematic rigour of the sciences. Völkerpsychologie, then, was meant to bridge the gap between 'natural history' and history, or the sciences and the humanities. Worded rather clumsily, Lazarus and Steinthal thus formulated the programme of a social science: Völkerpsychologie was conceived as a 'third way' between natural science and history, since it studied the human 'spirit', but with the methods of the sciences. ${ }^{22}$ The essence of the human spirit made such an approach necessary, since it operated, they argued, with the same law-like necessity as 
nature, but resulted in progress and development. The human 'spirit' was thus at the same time the highest creation of nature, but different from the 'realm of necessity': 'The lawlike constant activity of the spirit constitutes development, and progress is part of the nature of the spirit to such an extent that the spirit no longer belongs to nature. ${ }^{23}$

Lazarus and Steinthal saw the diversity of nations not primarily as a cause of conflicts, struggles, and warfare, but celebrated it as the precondition for the 'development of mankind' and the progress of culture and civilization. Völkerpsychologie would show how the diversity of nations contributed to this development and made the progress of the human spirit possible. ${ }^{24}$ Folk psychology would consist of two parts: "national-historical psychology' was intended to study the folk spirit theoretically as a general principle, while 'psychological ethnology’ would study 'really existing folk spirits'. Lazarus and Steinthal only contributed to the former, general, and theoretical part of folk psychology and left any empirical studies to potential followers of their approach; they did not produce systematic descriptions of the character of individual nations, even though they held clear views about the 'German character.' As convinced German nationalists, they believed in the superiority of the 'German spirit' as expressed in German philosophy, science, and literature. ${ }^{25}$ Not surprisingly, then, folk psychology was also intended to contribute to the national education of the Germans and thus to serve practical purposes. According to Lazarus, the study of Völkerpsychologie would help the Germans to become aware of their own folk spirit and prevent them from adopting foreign ideas that were ill-suited to their character. It was this

Ibid., pp. 17-18, 'Die gesetzmäßig gleichbleibende Thätigkeit des Geistes also ist Entwickelung, und der Fortschritt gehört so sehr zur Natur des Geistes, daß eben deshalb der Geist nicht zur Natur gehört.'

$24 \quad$ Ibid., pp. 5-6.

25 Ibid., p. 7. See David J. Rosenberg, 'Patho-Teleology and the Spirit of War: The Psychoanalytic Inheritance of National Psychology', Monatshefte, 100, 2008, 2, pp. 213-25 (215). 
socio-political purpose that proved to be the main problem for folk psychology. ${ }^{26}$

\section{The Reception and Critique of Völkerpsychologie}

From its inception, Lazarus and Steinthal's Völkerpsychologie received mixed reviews. Some reviewers agreed completely with their aims, ${ }^{27}$ others, such as Adolf Lasson (18321917), professor of aesthetics and literature at the University of Berlin, could not hide their sarcasm and poked fun at the over-ambitious plans of Lazarus and Steinthal. Lasson criticized the idea of a national 'soul' (Volksseele) without which there could not be a 'folk psychology', while Lazarus and Steinthal had replaced the idea of a national 'soul' because of its 'metaphysical' connotations and substituted 'folk spirit' for it. What Lazarus and Steinthal had in mind, Lasson continued, was old hat and existed already under the label 'cultural history'. The fashionable term Völkerpsychologie merely pretended to be innovative. Lasson represented a major line of criticism of folk psychology: he did not reject the legitimacy of studying the peculiarities of nations as expressed by their 'spirit', but rather the way in which Lazarus and Steinthal presented and advertised it. ${ }^{28}$ Others doubted the approach in its entirety. The novelist and philosopher of language, Fritz Mauthner (1849-1923), for instance, saw the need for a folk psychology as typical for the secular, modern age that required a post-religious 'identity'. Sarcastically, he pointed at

\footnotetext{
26 Lazarus and Steinthal, 'Einleitende Gedanken', p. 66.

27 Ludwig Noack, 'Die Idee der Völkerpsychologie' Psyche. Zeitschrift für die Kenntnis des Seelenund Geisteslebens, 2, 1859, 1, pp. 161-65. Anon., 'Zur Völkerpsychologie und Sprachwissenschaft' Blätter für literarische Bildung, 1861, 1, p. 355, Lazarus Schweiger, Philosophie der Geschichte, Völkerpsychologie und Soziologie in ihren gegenseitigen Wechselbeziehungen, Bern, 1899, pp. 65-78.
}

28 [Adolf] Lasson, review of Zeitschrift für Völkerpsychologie und Sprachwissenschaft, vol. 1, in Archiv für das Studium der neueren Sprachen und Literaturen, 25, 27, 1860, pp. 209-16. 
Lazarus and Steinthal as 'directors' of an enterprise that could not precisely define its main object of study, the 'folk spirit', and thus bordered on the occult. Still, Mauthner had learned particularly from Steinthal, especially when he defined language as a human activity and social phenomenon, not an entity. ${ }^{29}$ The cultural critic and Zionist, Max Nordau (1849-1923), who in his earlier writings had speculated about the character of Germanic and Romance peoples, denied the possibility of a folk psychology. In a study on 'The meaning of history', he criticized Lazarus and Steinthal because they had discarded 'race' as a factor by which to characterize nations: 'None of the great European nations studied by Völkerpsychologie is of unified blood'; therefore, Nordau argued, unified, homogeneous national characters did not exist. Language was no sign of a 'national soul', either; for Nordau, psychology could only study individuals. ${ }^{30}$

One of harshest critiques of Lazarus and Steinthal was published by the linguist Hermann Paul (1846-1921) as part of the introduction to his influential textbook, Principles of the history of language. ${ }^{31}$ A one-time student of Steinthal and follower of Herbart's psychology, Paul criticized the analogy Lazarus and Steinthal had drawn between individual and folk psychology. True to Herbart, he rejected the very idea of a 'folk spirit' with its own essence and agency: 'All psychological processes are conducted within the individual spirits, and nowhere else. Neither a folk spirit, nor elements of the folk spirit

Fritz Mauthner, Die Sprache, Frankfurt am Main, 1906, p. 9. See Fritz Mauthner, Beiträge zu einer Kritik der Sprache, 3 vols., Stuttgart 1901-02; Allan Janik and Stephen Toulmin, Wittgenstein's Vienna, Chicago, IL, 1996, pp. 126-27.

30

Max Nordau, Der Sinn der Geschichte, Berlin, 1909, pp. 136-47 (138): 'Kein großes Volk Europas, mit dem die Völkerpsychologie sich bisher beschäftigt hat, ist einheitlichen Blutes; [...]'. See Petra Zudrell, Der Schriftsteller und Kulturkritiker Max Nordau. Zwischen Zionismus, Deutschtum und Judentum, Würzburg, 2003, p. 39. 
such as art, religion etc. exist for real, hence nothing can happen within or between them. Away with these abstractions! ${ }^{32}$ While Paul agreed that the humanities (Kulturwissenschaften) had to be based on psychology - though not on psychology alone, since human culture equally depended on nature - psychology could only be individual psychology, since only individual 'souls' existed and interacted with each other. Therefore, Paul argued, the concept of a 'folk psychology' made no sense. Lazarus and Steinthal had failed to address the interaction between individuals and had instead speculated about a 'folk spirit' that did not exist. ${ }^{33}$

Responding to Paul's criticism, Wilhelm Wundt (1832-1920), who played a pivotal role in establishing psychology as an independent discipline, defended the general idea of a Völkerpsychologie. Long before he started publishing his own ten-volume magnum opus, from 1900 onwards, Wundt had been an attentive reader of Lazarus and Steinthal's journal. ${ }^{34}$ The second volume of his Vorlesungen über die Menschen- und Thierseele, published in 1863 , had been an early attempt at a folk psychology, even though he later dismissed it as a 'youthful folly'. ${ }^{35}$ In 1886 Wundt published a critical review of both Lazarus and Steinthal's approach to folk psychology and Paul's critique of it. Wundt agreed that psychology could not be restricted to the individual but had to include human society

\footnotetext{
32 Paul, Prinzipien der Sprachgeschichte, p. 11 ('Alle psychischen Prozesse vollziehen sich in den
} Einzelgeistern und nirgends sonst. Weder Volksgeist noch Elemente des Volksgeistes wie Kunst, Religion etc. haben eine konkrete Existenz, und folglich kann auch nichts in ihnen oder zwischen ihnen vorgehen. Daher weg mit diesen Abstraktionen.') 
as an object of study, and that the nation was therefore a natural object of study. ${ }^{36}$ Echoing Lasson's criticism, however, he denied the need for Völkerpsychologie to be established as an independent discipline that would reduce all existing humanities to a secondary status. Wundt doubted that it was possible to find 'historical laws' that were as accurate as laws of nature but, if so, historians would not leave it to folk psychologists to establish these laws. Wundt's aim was to develop psychology into a general social science which would be subdivided into individual psychology and Völkerpsychologie. He criticized Lazarus and Steinthal for trying to combine Herbart's psychology with Hegel's philosophy - in his view, a fatal mixture that had caused the conceptual confusion of their approach. Wundt's own Völkerpsychologie - published from 1900 to 1920 in ten massive volumes - was thus inspired by Lazarus and Steinthal, but differed in important respects. Even more so than their works, his relied on the assumption of progress in history and presented the history of mankind as the succession of four stages of progressive development, from a primitive age to totemism, heroism, and civilization. Wundt was convinced that folk psychology constituted the 'higher', more valuable part of psychology in contrast to the individual psychology which he practised as physiological psychology with experimental methods. Whereas Lazarus and Steinthal were only interested in Western nations - the 'historical' nations - and were mainly interested in studying their own nation, Wundt's Völkerpsychologie did not exclude non-European or non-literary civilizations. Lazarus and Steinthal's folk psychology was a form of Volkskunde, or folklore, defined in the German tradition as the study of common people and their language, customs, habits, and traditions - in 1890, the Zeitschrift für Völkerpsychologie und Sprachwissenschaft was taken over by

\footnotetext{
36 Wilhelm Wundt, 'Ziele und Wege der Völkerpsychologie' [1886]. Idem, Probleme der Völkerpsychologie, Leipzig, 1911, pp. 1-35 (2-3).
} 
the Verein für Volkskunde and became the Zeitschrift für Volkskunde. Wundt's folk psychology, in contrast, was a variety of Völkerkunde, or social anthropology, which studied mankind in a universal and comparative way. ${ }^{37}$

Despite the criticism it received, Lazarus and Steinthal's folk psychology inspired a number of reactions, which in turn contributed to the establishing of the social sciences. Steinthal - a more productive, thorough, and meticulous scholar than Lazarus - understood his linguistic works as studies in folk psychology, and as such he contributed to the establishing of modern linguistics. His three-fold definition of language as ability to speak (Sprachfähigkeit), language matter (Sprachmaterial), and speaking (Sprechen) reappeared as langage, langue, and parole in the lectures of Ferdinand de Saussure, who had been one of Steinthal's students at the university of Berlin. ${ }^{38}$ Most important for the legacy of Lazarus and Steinthal was Georg Simmel, who from 1890 taught as Privatdozent and adjunct professor at the University of Berlin and who became one of the intellectual stars of the German capital, although his established academic colleagues viewed his success as a teacher and author with jealousy and suspicion. Simmel had studied with Lazarus and Steinthal at the University of Berlin. His first academic publication, a version of his dissertation entitled 'Psychological and ethnological studies on music', was inspired by Steinthal's study on the 'Origin of language' and subsequently published in the Zeitschrift

37 Wilhelm Wundt, Völkerpsychologie. 10 vols., Leipzig, 1900-20. Idem, Elemente der Völkerpsychologie. Grundlinien einer psychologischen Entwicklungsgeschichte der Menschheit, Leipzig, 1912. On the history of Volkskunde see Regina Bendix, In Search of Authenticity: The Formation of Folklore Studies, Madison, WI, 1997.

38

Waltraud Bumann, Die Sprachtheorie Heymann Steinthals. Dargestellt im Zusammenhang mit seiner Theorie der Geisteswissenschaft, Meisenheim am Glan, 1966. Gerhart von Graevenitz, "“Verdichtung”. Das Kulturmodell der "Zeitschrift für Völkerpsychologie und Sprachwissenschaft”". Aleida Assmann (ed.), Positionen der Kulturanthropologie, Frankfurt am Main, 1994, pp. 148-71 (155-56). 
für Völkerpsychologie und Sprachwissenschaft. ${ }^{39}$ Especially in his early works, Simmel adopted central ideas of Lazarus and Steinthal's Völkerpsychologie. Lazarus's 'objective spirit' reappeared as Kultur in Simmel's works. Hence Simmel defined culture broadly, as in Lazarus and Steinthal's folk psychology, and saw it as comprising not only language, institutions, and art, but also technology. Simmel thus modernized Lazarus and Steinthal's terminology while keeping the main idea: to him, society had no substance - it was no 'organism', but represented instead the sum of the interactions of ideas held by individuals and groups. Simmel did not share the belief in progress that had underpinned Lazarus and Steinthal's thinking, and he stressed the restrictions that 'culture' or the 'objective spirit' imposed on the individual. He rejected the idea of psychology as a 'scientific' discipline, since no psychological laws could be established. And while one of his main interests lay in the formation of groups and communities, he did not share Lazarus and Steinthal's belief in the primordial importance held by the nation or Volk over other communities. Simmel reworked a number of central ideas of Völkerpsychologie such as the 'objective spirit' or 'interaction' which thus found entrance, in modified form, into the core of his writings. ${ }^{40}$

Even though their writings were never translated into English or French, Lazarus and Steinthal's ideas received attention outside Prussia and Germany. Before French sociologists and philosophers made their own contribution to establishing social

Georg Simmel, 'Psychologische und ethnologische Studien über Musik', Zeitschrift für Völkerpsychologie und Sprachwissenschaft, 13 (1882), pp. 261-305.

40 Georg Simmel, Über sociale Differenzierung. Sociologische und psychologische Untersuchungen, Leipzig, 1890; David Frisby, Simmel and Since. Essays on Georg Simmel's Social Theory, London and New York, 1992, pp. 28-29; Heinz-Jürgen Dahme and Otthein Rammstedt, 'Einleitung', Georg Simmel, Schriften zur Soziologie. Eine Auswahl, ed. by Heinz-Jürgen Dahme and Otthein Rammstedt, Frankfurt am Main, 1995, pp. 7-34. 
psychology around the turn of the century with the concept of 'crowd psychology', Lazarus and Steinthal's folk psychology was received well on the other side of the Rhine. The experimental psychologist Théodule Ribot (1839-1916), who was together with Hippolyte Taine one of the main opponents of philosophical 'spiritualism', appreciated their programme. Ribot considered Lazarus and Steinthal the 'true founders' of 'ethnic psychology' and commended them for insisting that the 'people' represented more than the sum of its part and had to be analysed systematically. ${ }^{42}$ The sociologist Celestin Bouglé (1870-1940), who, like many of his compatriots, had studied in Berlin, then worked with Émile Durkheim and became professor at the Sorbonne in 1908, presented Lazarus as one of the founders of the social sciences in Germany, alongside Georg Simmel, the economist Adolph Wagner (1835-1917) and the philosopher of law Rudolf von Ihering (1818-92). Bouglé paraphrased the main ideas of Lazarus and Steinthal's approach accurately and uncritically. The remaining weaknesses of their 'social psychology' were negligible, compared to their achievements; Lazarus, Bouglé claimed, had shown the way to overcome philosophical individualism by introducing 'social psychology'. ${ }^{4}$

In the United States of America, the sociologist William Isaac Thomas (1863-1947) of the 'Chicago School' of sociology was, like Georg Simmel, interested in those aspects of folk psychology that allowed for the study of everyday life. Thomas had studied folk

41 Gabriel Tarde, Les Lois de l'imitation. Étude sociologique, Paris, 1890; Gustave Le Bon, Psychologie des foules, Paris, 1895; Robert A. Nye, The Origins of Crowd Psychology. Gustave Le Bon and the Crisis of Mass Democracy in the Third Republic, London and Beverly Hills, CA, 1975.

42 Théodule Ribot, La Psychologie allemande contemporaine (École expérimentale), Paris, 1879, pp. 49-57; Nye, The Origins, p. 13. 
psychology at the University of Berlin in $1888 / 89 .^{44}$ The most important and influential student of Völkerpsychologie in the United States of America was Franz Boas (1858-1942). A student of the ethnologist Adolf Bastian, an early contributor to Lazarus and Steinthal's journal, the founding father of 'cultural anthropology' integrated linguistic research into his holistic concept of anthropology that would become the dominant approach in the United States. In a famous essay on the history of anthropology, a kind of a manifesto of the Boasschool, he referred to 'folk psychology' as the major influence for linguisticanthropological studies. ${ }^{45}$ In its comprehensive outlook, Boas's anthropology resembled folk psychology since it studied all manifestations of the Volksgeist - language, myths, religion, and art; in addition, Boas actively rejected scientific racism. ${ }^{46}$ In contrast to Lazarus and Steinthal, however, Boas abandoned the idea of a hierarchy of civilizations with its Eurocentric bias and replaced it with a pronounced relativistic view; no 'culture' was deemed more worthy than any other, and all cultures merited study for their own sake. In contrast to Lazarus and Steinthal, Boas's cultural anthropology was an empirical discipline attentive to methodological problems that could not be practised from the convenience of an armchair. As a true synthesis of the disciplines that studied 'man', Boas defined 'cultural anthropology' as a combination of Völkerpsychologie, ethnology, and physical anthropology. Being a very successful teacher - Alfred Kroeber, Edward Sapir,

44 Martin Bulmer, The Chicago School of Sociology. Institutionalisation, Diversity, and the Rise of Sociological Research, Chicago, IL, 1984, p. 36; see William I. Thomas, 'The Scope and Method of FolkPsychology', American Journal of Sociology, 1, 1896, pp. 434-45.

45 Franz Boas, 'The History of Anthropology', Science, 20, 1904, 512, pp. 513-24 (518).

46 Matti Bunzl, 'Völkerpsychologie and German-Jewish Emancipation', in Hugh Glenn Penny and Matti Bunzl (eds), Worldly Provincialism. German Anthropology in the Age of Empire, Ann Arbor, MI, 2003, pp. 47-85 (82-85). 
Ruth Benedict, and Otto Klineberg were among his many students - Boas planted some of the essential ideas of Völkerpsychologie in American cultural anthropology. ${ }^{47}$

However, what may well have been the very first attempt to present a coherent system of 'social psychology' was not developed in the USA, where the discipline would boom in the twentieth century, especially after the Second World War, but in the Habsburg Empire, by the Austrian educationalist and philosopher Gustav Adolf Lindner, in direct response to Lazarus and Steinthal's Völkerpsychologie. Mostly forgotten as an early social scientist, Lindner's influence as the author of textbooks for the secondary schools of the Habsburg Empire cannot be underestimated. His textbooks on empirical psychology, logic, and philosophy became the standard texts throughout the empire and introduced generations of students to these fields; they were still in print long after his death. Indeed, both the young Sigmund Freud and Franz Kafka studied Lindner's Lehrbuch der empirischen Psychologie in their final year at the Gymnasium. ${ }^{48}$ Lindner (1828-87) was born in a bilingual family in Rosdalowitz in Bohemia and was a student of Franz Exner at the University of Prague in the 1840s. Through Exner, Lindner became a loyal follower of Herbart, and with his textbooks contributed to making Herbartianism the 'official' philosophy of higher education in the Habsburg Empire. After a career as a schoolteacher and school inspector, he became professor for pedagogy, psychology, and ethics at the University of Prague in 1878, and in 1882 decided to join the Czech university when it was

See George W. Stocking Jr., 'Franz Boas and the Culture Concept in Historical Perspective'; idem, Race, Culture and Evolution, New York, 1968, pp. 195-233; id. (ed.), Volksgeist as Method and Ethic. Essays on Boasian Ethnography and the German Anthropological Tradition, Madison, WI, 1996.

48 See Ernest Jones, The Life and Work of Sigmund Freud, vol. 1, London, 1953, p. 409-10; Wilhelm W. Hemecker, Vor Freud. Philosophiegeschichtliche Voraussetzungen der Psychoanalyse, Munich, 1991, pp. 108-28; Peter-André Alt, Franz Kafka. Der ewige Sohn, Munich, 2006, p. 79. 
divided along national lines, thus becoming a senior colleague of the young Tomás Masaryk. $^{49}$

Next to his introductory textbooks, Lindner's major contribution to the scholarly literature was a general psychology, published in two volumes. The first one, with the quirky title 'The problem of happiness', was dedicated to individual psychology, the second volume introduced the term 'social psychology'. 50 To Lindner, social psychology and economics together formed the two, 'inner' and 'outer' parts of social science. He agreed with Lazarus and Steinthal that man as a social being needed to be studied as part of a community. Through their interactions, individuals created and constituted 'society'. Lindner accordingly defined social psychology as the discipline that studied psychological interactions within society that produced law-like regularities in the human world. As he wrote, 'The task of social psychology is the description and explanation of phenomena which depend on the interaction of individuals and on which rest the whole mental life of society.' In contrast to Lazarus and Steinthal, and in accordance with the Herbart-school, Lindner claimed that society did not exist independently of the individuals; the 'mental life' of society could only be found in the individual consciousness of its members. Hence, social psychology could borrow its principles from individual psychology. ${ }^{51}$

What, then, represented 'society'? Lindner found two 'natural creations in the Psychology, Cambridge, 2007, pp. 59ff. On Franz Exner see Deborah Coen, Vienna in the Age of Uncertainty. Science, Liberalism and Private Life, Chicago, IL, and London, 2007, pp. 33-63.

Gustav Lindner, Das Problem des Glücks. Psychologische Untersuchungen über die menschliche Glückseligkeit, Vienna, 1868. Idem, Ideen zur Psychologie der Gesellschaft als Grundlage der Sozialwissenschaft, Vienna, 1871. 
history of mankind' that could thus be the object of study of social psychology: nations and states (Völker und Staaten). Both nations and states formed coherent entities, but for different reasons: nations were defined by the common descent and common language of their members, while states comprised a common territory and a common legal order. Indeed, 'nationhood' (Volksthum) appeared as the expression of the most intensive mental interaction of a majority of people. ${ }^{52}$ But in contrast to Lazarus and Steinthal, who had never cast any doubt on the importance of the nation, Lindner argued that since nations changed during the course of history, and were lumped together in polyglot states, the state was the more appropriate representation of society (Urbild der Gesellschaft), and thus the most appropriate object of enquiry in the social sciences. Lindner highlighted further differences between his social psychology and Lazarus and Steinthal's Völkerpsychologie. While he focused on 'real personalities and their interactions', folk psychology studied the 'abstract emanations of the folk spirit', that is, language, religion, mythology, and art: 'In short, social psychology deals with the mental personality of society itself, while folk psychology deals with single mental utterances; the latter follows the course of history, while the former strictly adheres to the teachings of psychology, and relies on history only to test its hypotheses. ${ }^{53}$ Despite this critical attitude towards folk psychology, Lindner believed that both disciplines could co-exist; but in his view, folk psychology would provide the empirical-historical material that social psychology would interpret and explain. $^{54}$ Verdichtung der geistigen Wechselbeziehungen in einer Mehrheit von Menschen.' 
The differences between Lindner's social psychology and Lazarus and Steinthal's folk psychology directly reflected their different national backgrounds and experiences. Even though Lindner did not stick to his neat differentiation between state and nation in the course of his study, his preference for the state over the nation as representing 'society' suited the requirements of an 'official' social science for the multinational and multilingual Habsburg empire. By contrast, Lazarus and Steinthal's focus on the Volk and the nation reflected their identification with Prussia and the Prussian-dominated German empire. The bilingual Lindner, who tried to mediate between German and Czech interests, played down the importance of nationality within the larger state. His social psychology was a product of the political outlook of the multinational Habsburg Empire and of its 'backward' political structures, although, with hindsight, these now appear more 'modern' than Lazarus and Steinthal's folk psychology and its romanticist terminology. Faithful to Herbart, Lindner got rid of the idea that the nation represented 'more than the sum of its part', the Volksgeist, one of the main stumbling blocks of Völkerpsychologie. Society was constituted by the interaction of individuals through communication, and produced regularities that the social sciences had to study, preferably on the basis of statistical data.

\section{Völkerpsychologie, Antisemitism, and the Ethics of Judaism}

After his return to Prussia in 1865, Lazarus became increasingly involved in Jewish organizations and associations and became one of the most prominent representatives of the Reform movement in Judaism in Germany. He was a member of the board of the GermanIsraelite Community Association (Mitglied des Präsidiums des Deutsch-Israelitischen Gemeindebundes), and in 1869 and 1872 he presided over the Israelite synods in Leipzig 
and Augsburg. ${ }^{55}$ One of the results of the meeting in Leipzig was the founding of the College for the Study of Judaism (Hochschule, from 1883 the Lehranstalt für die Wissenschaft vom Judentum) in Berlin, an initiative that owed much to Lazarus's efforts. He subsequently became chairman of the board of this central institution which trained reform-orientated rabbis and conducted independent research. Steinthal taught at the Hochschule from $1872 .^{56}$

In his role as a leading representative of the Jewish community in Berlin, Lazarus reacted to the growing antisemitism in the German Empire in the late 1870s. The degree and depth of antisemitism after the economic crash in 1873 had taken the convinced Prussian and German nationalist by surprise, ${ }^{57}$ and when the court preacher Adolf Stoecker (1835-1909) and the historian Heinrich von Treitschke (1834-96) seemed to make antisemitism respectable, Lazarus publicly defended the German Jews against their discrimination as a 'foreign nation' within Germany. ${ }^{58}$ To this end, Lazarus referred back to the definition of the nation he had given in the first issue of the journal on Völkerpsychologie almost twenty years earlier. Again, Lazarus rejected attempts to define nationality by 'objective' criteria such as descent, morals, customs, a common territory, or religion. In reality, nationality was the subjective choice of individuals: 'The real nature and true essence of nationality can only be understood out of its spirit.' The concept of the 'people' or 'nation' - to Lazarus, both terms were synonyms - rested on the 'subjective

See Lazarus's speeches at the synods in M. Lazarus, Treu und Frei. Gesammelte Reden und Vorträge über Juden und Judenthum, Leipzig, 1887, pp. 1-53.

56 Michael A. Meyer, Response to Modernity. A History of the Reform Movement in Judaism, Detroit, MI, 1995, pp. 189-91. 
view of the members of the people themselves about their equality and shared identity (Zusammengehörigkeit), ${ }^{59}$ This definition left no doubts about the answer to the title question of his speech: the German Jews were 'Germans, nothing but Germans, when the concept of nationality is concerned, we belong to only one nation, that is the German nation. ${ }^{60}$ Their religion did not turn the Jews into a nation, but a 'tribe' (Stamm); Judaism had to be viewed as one of several confessions that co-existed in the German nation.

Even though Lazarus openly opposed Jewish orthodoxy, he denied the need for the Jews to give up their religion and convert to Christianity as a way of solving the 'Jewish question'. Already 'complete, highly able and productive Germans', the Jews had to remain Jews in Germany. As such, the peculiarities and special traits of the Jewish 'tribe' would contribute to 'fulfilling the highest ideal of German nationality'. According to Lazarus, the Jews had a special role to fulfil as part of the German people. They were obliged to preserve their heritage and 'put it into the service of the German folk spirit'. ${ }^{61}$ The Jews were characterized by a specific communal spirit that had developed out of their religious traditions and expressed itself in ethical ideals. ${ }^{62}$ In Lazarus's view, the Jews appeared as special Germans whose secular ethics had made them the foremost bearers of humanitarian progress. For this reason, he was strongly in favour of pluralism within a nation; indeed, he declared the great diversity (Mannigfaltigkeit) of a nation as a prerequisite for the progress of the folk spirit. 'Diversity' encapsulated 'true culture'; accordingly, 'each nationality (Volkstum) which is to reach a high level of development has to be equipped with a great 
diversity of talents and ambitions (Bedingungen sowohl, wie der Bestrebungen). ${ }^{63}$ Thus Lazarus had made a small, but important change to his original argument. Whereas in the earlier texts on Völkerpsychologie the nation had appeared as an harmonious entity that was created by the folk spirit, he now presented the nation as a diverse unity that benefited from internal pluralism, that is, from the variety of Stämme, confessions, and classes it was made up from. For this reason, the Jews had to preserve their intellectual and ethical heritage and contribute it to the greater good of the German nation.

Lazarus's arguments succinctly summarized the self-image of liberal, reformminded Jews in the German Empire as well as its problems, and as such they were rejected by both Heinrich von Treitschke as well as by Hermann Cohen (1842-1918), a former student of Lazarus and Steinthal who became a main representative of Neo-Kantianism. Treitschke declared that whereas Christianity was woven into the German people with all its fibres, Judaism was the national religion of an 'originally alien tribe' (eines ursprünglich fremden Stammes). He accused Lazarus of ignoring the difference between a religion and a confession, while the co-existence of several religions within one nation could only be seen as a transitional stage. Instead of the tolerant, productive, and harmonious co-operation of several confessions for the higher good that Lazarus had in mind, Treitschke saw the only solution of the 'Jewish question' in the conversion of the Jews. ${ }^{64}$ Personally more disappointing than Treitschke's response was Hermann Cohen's reply to his speech. ${ }^{65}$

63 Ibid., pp. $91,93$.

64 Heinrich von Treitschke, 'Noch einige Bemerkungen zur Judenfrage' [1880], in Walther Boehlich (ed.), Der Berliner Antisemitismusstreit, Frankfurt am Main, 1965, pp. 77-90 (86-87).

$65 \quad$ Ulrich Sieg, Aufstieg und Niedergang des Marburger Neukantianismus. Die Geschichte einer philosophischen Schulgemeinschaft, Würzburg, 1994, pp. 108-10; see Hermann Cohen, 'Die platonische Ideenlehre psychologisch entwickelt' Zeitschrift für Völkerpsychologie und Sprachwissenschaft, 4, 1866, pp. 
Cohen agreed with Treitschke on most points and was much more critical of Lazarus's reformist agenda. He denied that the Jews had a special moral-intellectual role to play in Germany, and accordingly opined that Jews could not contribute anything specific to the German 'folk spirit'. Like Treitschke, Cohen urged the Jews to assimilate completely into the German nation, not only in an intellectual-cultural way, but also in their physiognomy. The Jews had to show the ambition to get rid of their 'peculiarities' and not to cultivate these, since this would indeed constitute a 'nation within a nation' which had to be avoided by all means: 'A dual national allegiance is not only immoral, but impossible. ${ }^{, 66}$

One of the most famous texts of one of the most influential and celebrated French intellectuals of the nineteenth century adopted one of the cornerstones of Lazarus's folk psychology, that is, the voluntaristic and subjective definition of the nation. Lazarus claimed in his autobiography that Ernest Renan had copied the central points of his lecture 'Qu'est-ce que une nation?', delivered in 1882 at the Sorbonne, directly from his speech 'Was heißt national?'. One of Lazarus's students, the teacher Alfred Leicht, who edited his autobiographical writings and tried to preserve his image for posterity, even accused Renan of plagiarism since he did not reference Lazarus in his lecture. ${ }^{67}$ It is certainly possible that Renan, a scholar who was very familiar with German philosophy and studies in the

403-64; idem, 'Mythologische Vorstellungen von Gott und Seele' Zeitschrift für Völkerpsychologie und Sprachwissenschaft, 5, 1868, pp. 396-434; Christian Köhnke, “"Unser junger Freund”- Hermann Cohen und die Völkerpsychologie' Wolfgang Marx and Ernst Wolfgang Orth (eds.), Hermann Cohen und die Erkenntnistheorie, Würzburg, 2001, pp. 62-77; Ulrich Sieg, 'Der frühe Hermann Cohen und die Völkerpsychologie' Aschkenas, 13, 2003, pp. 461-83.

Hermann Cohen, 'Ein Bekenntnis in der Judenfrage' [1880], in Boehlich, Berliner Antisemitismusstreit, pp. 124-49 (136-37, 139), 'Ein nationales Doppelgefühl ist nicht nur ein unsittlich Ding, sondern ein Unding.' 
humanities, found much of his inspiration in Lazarus's text. ${ }^{68}$ Regardless of questions of intellectual property, the similarities between both texts are striking: like Lazarus, Renan rejected all 'objective' definitions of the nation, from language to territory and race, and illustrated this with examples from European history. In contrast to Lazarus, however, Renan argued that a 'national spirit' depended as much on common memory as on forgetting, an argument that recalls Nietzsche's 'monumental history'. To create a strong and powerful national spirit, it was not only necessary to accumulate knowledge and thus elevate the 'national spirit', but also to cast aside national traumas, and delete the memory of negative historical experiences. A nation needed to be re-enacted constantly, a mechanism for which Renan coined the catch-phrase of the nation as a 'daily plebiscite'. In addition, Lazarus's and Renan's text had the same target, namely the German-Prussian nationalists who tried to 'complete' the political unification of Germany by targeting alleged enemies of the nation: Catholics, socialists, and Jews. But whereas Lazarus employed his definition of the nation to defend the rights of the German Jews as German citizens, Renan used the same idea to argue against German claims to the annexed regions of the Alsace and Lorraine as 'naturally' German provinces.

The debate about antisemitism in 1879-81 was the main reason for Lazarus's decision to embark upon a major book project, a comprehensive study of the 'Ethics of Judaism' that would occupy him for the rest of his life. In the wake of the debate, a meeting of representatives of reformist Jewish communities from Paris, London, Berlin, and Vienna decided to commission a working group, chaired by Lazarus, to produce a reliable work on Jewish ethics. After difficulties with the financing of the project had arisen - donations 
from wealthy Jewish citizens did not materialize so that the necessary number of researchers could not be employed - Lazarus decided to write the 'Ethics' on his own. During his lifetime, Lazarus managed only to finish the first volume of the Ethics of Judaism, which was published in 1898, English and French translations followed soon afterwards. ${ }^{69}$ Reflecting his political-social consciousness as a liberal reformist German Jew, Lazarus tried to synthesize 'Kant and Judaism' and presented the Ethics of Judaism as embodying universal values. He wanted to show that the continuous Jewish tradition was the real origin of modern humanism. ${ }^{70}$ With this claim he represented the dilemma and the inner contradictions of reform Judaism, for he reserved a privileged position for the unique Jewish 'spirit', but at the same time conceived the Jewish spirit as universal and progressive. ${ }^{71}$ Similar to non-Jewish-liberals, he presented his own political-social and moral values as universal and generally valid. In addition, and not unlike his antisemitic opponents, he essentialized the 'Jewish spirit', but did not associate it with negative, but positive connotations, since it embodied a general ideal of mankind. ${ }^{72}$

For his part, Steinthal represented this dilemma of reform Judaism in much the same way as Lazarus. Even though less exposed in public life than Lazarus, he was involved in several Jewish organizations, published regularly in the Zeitschrift des Judentums, and responded to antisemitic accusations with the same vigour and conviction. To Steinthal,

69 M. Lazarus, Die Ethik des Judenthums, vol. 1, Frankfurt am Main, 1898.

70 Pinchas E. Rosenblüth, 'Die geistigen und religiösen Strömungen in der deutschen Judenheit' in Werner E. Mosse, Arnold Paucker, eds, Juden im Wilhelminischen Deutschland, 1890-1914, 2nd edn, Tübingen, 1998, pp. 549-98 (569-72).

71 Rosenblüth, 'Die geistigen und religiösen Strömungen', p. 573.

72 Uffa Jensen, Gebildete Doppelgänger. Bürgerliche Juden und Protestanten im 19. Jahrhundert, Göttingen, 2005, p. 88. 
Judaism equalled moral-intellectual progress and was thus a vital part of the national spirit: 'Judaism equals humanity; and since humanism can be reconciled with any nationality, if the nation really aspires to it, so Judaism can be reconciled with any nationality. ${ }^{, 73}$ Steinthal claimed that their 'double heritage' had turned the German Jews into better Germans because they combined German culture and Bildung with Jewish ethics.

Both Lazarus and Steinthal saw no conflict between folk psychology and their interest in 'Ethics' - Steinthal published his own General Ethics in $1885 .^{74}$ Lazarus presented 'folk psychology' as a discipline created on the 'basis of Judaism' whose ideas 'originated from the deepest sources of Judaism'. His studies on folk psychology had reconfirmed his identification with the Jewish faith and its ethical principles. ${ }^{75}$ To Steinthal, ethics and Völkerpsychologie were intricately connected, since ethics did not start with the individual, but with the national community. The 'spirit' of the individual was rooted in the community, which was therefore the starting point both of folk psychology and of any kind of ethics. ${ }^{76}$ With hindsight, Lazarus saw his childhood experiences in the tri-lingual town of Filehne in the province of Posen as a reason for his life-long interest in Völkerpsychologie. ${ }^{77}$ Appropriately, Lazarus's last public speech, made in Vienna in 1897 to much acclaim, was dedicated to a 'national-psychological study of Judaism', thus

73 Heymann Steinthal, 'Judentum und Patriotismus [1892]', in idem, Über Juden und Judentum. Vorträge und Aufsätze, ed. Gustav Karpeles, Berlin, 1906, pp. 67-70 (69).

74 H. Steinthal, Allgemeine Ethik, Berlin, 1885.

75 Lazarus to the teaching staff of the Hebrew Union College, Cincinnati, 7 May 1895, Belke, Lazarus, vol. 1, p. 205.

76 H. Steinthal, 'Herrn Prof. Dr. M. Lazarus zu seinem fünfundzwanzigjährigem Doktorjubiläum am 30. November 1874' in H. Steinthal, Über Juden und Judentum, pp. 238-42 (239).

77 Moritz Lazarus, Aus meiner Jugend, ed. Nahida Lazarus, Frankfurt am Main, 1913, p. 32; see Köhnke, 'Einleitung', p. xxiii. 
combining the topics that had dominated his academic work and his activities as a 'public intellectual' ${ }^{78}$

\section{Conclusion}

Lazarus and Steinthal's Völkerpsychologie epitomized the mentality of nineteenth-century liberals with its belief in science, progress, and the nation; it was reinforced by their experience of Jewish emancipation. It was not an early form of scientific racism, ${ }^{79}$ but contributed to the formation of the social sciences. Folk psychology had inherent weaknesses and contradictions, such as the circular definition of the Volk and the Volksgeist and the untimely attempt to establish a super-discipline that would relegate all exisiting disciplines to secondary status. Nevertheless, central aspects of the works of Georg Simmel and Franz Boas, 'founding fathers' of sociology and cultural anthropology respectively, were inspired by their reading of folk psychology and appropriated key concepts of Lazarus and Steinthal's works. Additionally, the first attempt at formulating a coherent 'social psychology', published by the Austrian educationalist Gustav Lindner in 1871, was itself a critical reply to Lazarus and Steinthal's Völkerpsychologie. Moreover, Lazarus and Steinthal themselves, while sketching the programme for a future folk psychology, suggested a definition of the 'nation' that inspired Renan's famous text on the same subject, predating by more than a century the deconstructivist idea of nations as 'imagined

\footnotetext{
78

Belke, Lazarus, vol. 1, p. 227.

79 Compare Manfred Dierks, 'Thomas Mann und die "jüdische” Psychoanalyse. Über Freud, C. G. Jung, das “jüdische Unbewußte” und Manns Ambivalenz', in idem and Ruprecht Wimmer, eds, Thomas Mann und das Judentum, Frankfurt am Main, 2004, pp. 97-126 (100); see Adrian Brock, 'Was Wundt a “Nazi”?', Theory and Psychology 2, 1992, 2, pp. 205-23.
} 
communities' or 'invented traditions', as popularized in the $1980 \mathrm{~s}{ }^{80}$

In the 1870 s and 1880 s, Lazarus used this definition of the nation to counter antisemitic arguments, thus shifting the focus of folk psychology from academic matters to socio-political debates. Lazarus and Steinthal were transitional figures; their writings provide a link between the philosophy of Herbart, Humboldt, and Hegel, and pioneers of the social sciences in the early twentieth century. Folk psychology was an attempt to provide an alternative to both historicism and philosophical idealism, but kept much of its romantic terminology, most importantly the concept of the Volksgeist. Hence Lazarus and Steinthal were not representatives of 'cultural sociology' or 'cultural philosophy' that formed around the turn of the century; their writings predated the inflationary use of the term 'culture' by several decades, and lacked the notion of a crisis of rationality that underpinned the debates about a general crisis of culture. True to the dominant views of nineteenth-century middle-classes, their belief in universal progress was as strong as their admiration of the success of the sciences. ${ }^{81}$

Even though Lazarus and Steinthal dismissed much of what had been written on nations and their characters as philosophical speculation, political journalism and metaphysics, and prided themselves in their allegedly scientific, objective approach to studying the Volksgeist, their Völkerpsychologie was value-laden and partisan. This did not

Renan, 'Qu'est-ce que une nation?'. Benedict Anderson, Imagined Communities. Reflections on the Origin and Spread of Nationalism, revised edn, London, 1991. Eric Hobsbawm and Terence Ranger (eds.), The Invention of Tradition, Cambridge, 1983.

81 Compare Köhnke, 'Einleitung'; Ivan Kalmar, 'The Völkerpsychologie of Lazarus and Steinthal and the Modern Concept of Culture', Journal of the History of Ideas, 48, 1987, 4, pp. 671-90; Rüdiger vom Bruch, Friedrich Wilhelm Graf, and Gangolf Hübinger (eds.), Kultur und Kulturwissenschaften um 1900. Krise der Moderne und Glaube an die Wissenschaft, Stuttgart, 1989. 
strike Lazarus and Steinthal as problematic since they never doubted the moral value of the nation, and indeed celebrated it as as the prerequisite of all culture and civilization. Folk psychology did not only study the folk spirit, but contributed to its progress. Thus, in the view of its founders, the repackaging of central ideas of folk psychology to counter antisemitism did not pose a problem, but reconfirmed the usefulness and legitimacy of their approach. Neither was Lazarus's work on the Ethics of Judaism, in his view, a distraction from Völkerpsychologie; rather, it was a study of the essence of the Jewish spirit and, as such, his major contribution to folk psychology. With this reformulation of the basic idea of folk psychology, Lazarus and Steinthal ran into trouble, since they denied that the Jews constituted a nation of their own, but at the same time averred the importance of the Jewish spirit. 